\title{
THE BRAIN
}




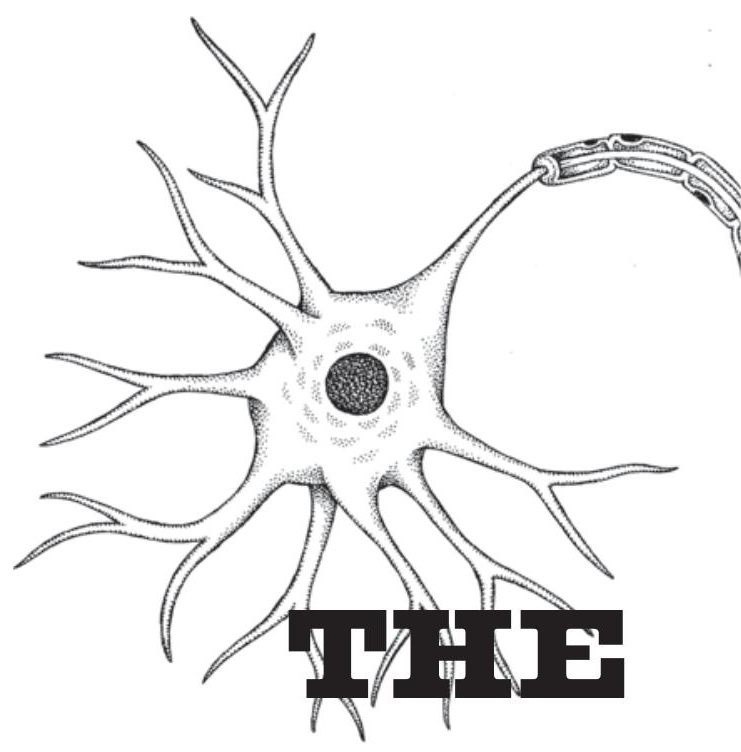

Rob DeSalle \&

Ian Tattersall

Illustrated by Patricia J. Wynne

Yale university PRESS

NEW HAVEN \& LONDON 


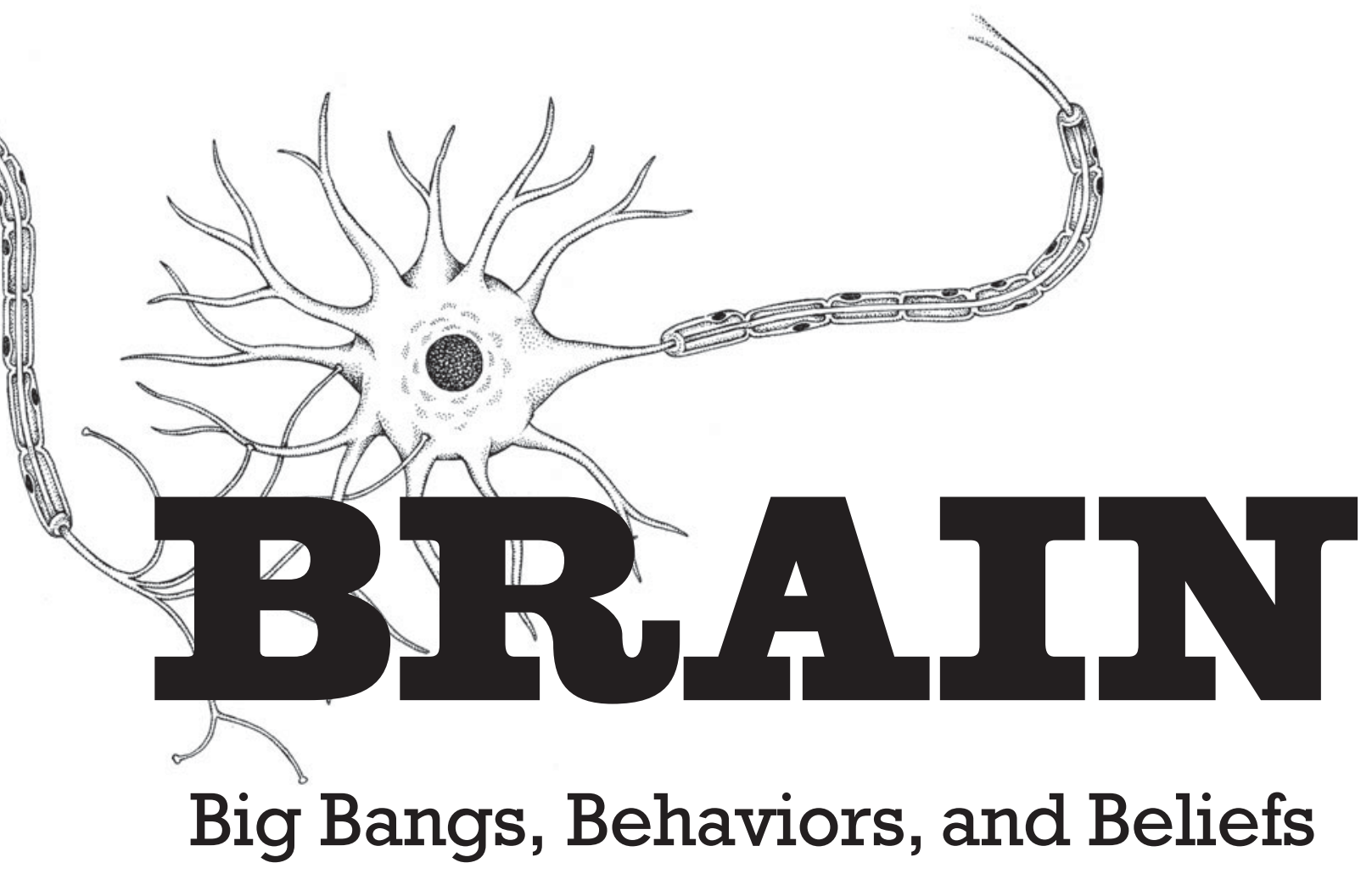


Published with assistance from the Louis Stern Memorial Fund.

Copyright (C) 2012 by Rob DeSalle and Ian Tattersall.

All rights reserved.

This book may not be reproduced, in whole or in part, including illustrations, in any form (beyond that copying permitted by Sections 107 and 108 of the US Copyright Law and except by reviewers for the public press), without written permission from the publishers.

Yale University Press books may be purchased in quantity for educational, business, or promotional use. For information, please e-mail sales.press@yale.edu (US office) or sales@ yaleup.co.uk (UK office).

Designed by Lindsey Voskowsky.

Set in Joanna MT type by Westchester Book Group.

Printed in the United States of America.

Library of Congress Cataloging-in-Publication Data

DeSalle, Rob.

The brain : big bangs, behaviors, and beliefs / Rob DeSalle and Ian Tattersall ; illustrated by Patricia J. Wynne.

p. $\mathrm{cm}$.

Includes bibliographical references and index.

ISBN 978-0-300-17522-6 (clothbound : alk. paper) 1. Cognition.

2. Neurophysiology. 3. Brain-Evolution. I. Tattersall, Ian. II. Title.

BF311.D466 2012

$612.8^{\prime} 2-\mathrm{dc} 23$

2011044329

A catalogue record for this book is available from the British Library.

This paper meets the requirements of ANSI/NISO Z39.48-1992 (Permanence of Paper).

$\begin{array}{llllllllll}10 & 9 & 8 & 7 & 6 & 5 & 4 & 3 & 2 & 1\end{array}$ 
For Erin, Jeanne, and Maceo 
This page intentionally left blank 